\title{
Equilibrium
}

Quarterly Journal of Economics and Economic Policy

VOLUME 8 ISSUE 4, 2013

ISSN 1689-765X, (Online) ISSN 2353-3293

http://www.equilibrium.umk.pl/

Lechman E. (2013), New Technologies Adoption and Diffusion Patterns in Developing Countries. An Empirical Study for the Period 2000-2011, "Equilibrium. Quarterly Journal of Economics and Economic Policy”, Volume 8, Issue 4, pp. 79-106, DOI: http://dx.doi.org/10.12775/EQUIL.2013.028

Ewa Lechman*

Gdansk University of Technology, Poland

\section{New Technologies Adoption and Diffusion Patterns in Developing Countries. An Empirical Study for the Period 2000-2011}

JEL Classification: $011,033,05$

Keywords: Information and Communication Technologies, adoption patterns, technology diffusion, $S$-shaped curve, developing countries

\begin{abstract}
In recent years, enormous changes are noted worldwide during broad adoption of Information and Communication Technologies (ICT). These unique technologies - often perceived as economic development incentives - have a great ability to spread at high pace and low cost in countries all over the world, bringing people opportunities to contribute to economic development and growth. New Technologies play a special role in developing countries, where their in-country adoption lies in the centre of development strategies. ICT are treated as tools which bring people access to information, education and knowledge, offering unlimited possibilities for wealth-creation.

The paper, purely empirical in nature, reports on the pace of adoption of new Information and Communication Technologies in developing countries, and - additionally - investigates country-specific ICT diffusion patterns. We expect to uncover the $S$-shape curve in the diffusion process in most of developing countries, as well as in the whole country sample.

For the analysis purposes, we apply all counties which-according to the World Bank nomenclature - are classified as low-income and lower-middle-income econ-
\end{abstract}

(C) Copyright Institute of Economic Research \& Polish Economic Society Branch in Torun Date of submission: January 5, 2013; date of acceptance: August 14, 2013

*Contact: eda@zie.pg.gda.pl , Gdansk University of Technology, Faculty of Management and Economics, ul. Narutowicza 11/12, 80-233 Gdańsk, Poland 
omies. Our sample covers 46 countries (upper-middle-income and high-income economies are excluded from the study purposefully) which are classified as developing economies. The time framework is set for the period of 2000-2011. All data necessary for the analysis are derived from World Telecommunication/ICT Indicators Database 2012 (16 ${ }^{\text {th }}$ edition).

\section{Introduction}

Recently, pervasive explosion of Information and Communication Technologies (ICT) is worldwide. The process of diffusion of ICT is associated with the spread of new ideas, knowledge and information. These technologies provide new ways of mass communication, process of storing and processing all knowledge and information. ICT are widely recognized as an effective tool for promoting economic growth and overall socio-economic development. By creating a bundle of possibilities on education, running a business or inclusion of socially and economically deprived groups, they provide a good basis for wealth creation. Wireless networks have enabled to open up economic "enclaves" by elimination of barriers such as i.e. geographical distance or information asymmetry. At a time, due to broad ICT adoption, society members gain an opportunity for wide and unlimited access to different kinds of knowledge, information, which enable them to improve their professional skills.

The main target of study is to elaborate ICT diffusion trajectories in developing countries. We hypothesise on existing specific ICT diffusion paths that can be approximated by "traditional" S-shaped curve, however anticipating that different technologies shall exhibit different diffusion paths. On that basis, we elaborate a specific time-series analysis, trying to capture characteristic phases of growth, which are easily distinguishable on theoretical S-shaped trajectory. The analysis is set rather as descriptive and not probabilistic in kind.

The sample selected for the analytical purposes consists of 46 low-, and lower-middle-income countries, for which we have chosen 3 variables explaining the level of ICT adoption and usage within analyzed economies. These are: the share of total population using (having access to) fixed telephone lines; the share of population using mobile phones; and - the share of population (individuals) using the Internet. All data are derived from International Telecommunication Database, and the analysis period is set for years 2000-2011.

The paper is structured as follows. In the first part, we clarify theoretical background on technology diffusion. The empirical part, followed by a short section explaining the data rationale, constitutes the main body of the text. It closes up with general finding and conclusions. 


\section{Technology Diffusion - General Conceptualization}

Conceptually, discussion on "technology diffusion" started with Joseph Schumpeter $(1934,1947)$, and his pioneering work emphasising process of technology (innovation) diffusion. In his works, Schumpeter argued that the process of technology diffusion is mostly linear. However, further studies on the phenomenon have shown that the process of adoption of invention is far from linear. In the fifties, due to some theoretical discussions on technology diffusion, new concepts of epidemic models emerged ${ }^{1}$. The models were based on some analogies between the process of technology diffusion and diffusion of contagious diseases. The epidemic models were claimed to be correct by Mansfield (1968), Metcalfe (1988), Karshenas and Stoneman (1995), Stoneman $(2001,2005)$. However, the epidemic models of technology diffusion were "blind" for dynamics of the process, and ignored societal, educational, demographical or economic conditions, which highly influence the rate and pattern of technology diffusion.

Now, theoretical and empirical analysis of technology diffusion, mostly refers to the seminal concept of Everett Rogers (see Rogers 1962, 1995), explaining diffusion process of innovation (Rogers presumes that the word "technology" is a synonymous to "innovation". As a consequence, Rogers uses these two alternatively, along with the diffusion rates and stages. His concepts and theoretical framework (model) of technology diffusion are widely applied in political sciences, economics, public health policies, history or education. For Rogers $(1962,1995)$, the term "technology" stands for "design for instrumental action that reduces the uncertainty in the causeeffect relationships involved in achieving a desired outcome" (Rogers 1962, p. 6). He (see Rogers 1962, p. 10) defines the diffusion "as a process by which an innovation (technology - author's note) is communicated through certain channels over time among members of a social system". Following the previous, the process of technology diffusion covers 4 aspects (elements): innovation (defined as "an idea, practice, or project that is perceived as new (...) (Rogers 1962, p. 12)), communication channels ("process in which participants create and share information", (Rogers 1962, p. 5), time (time in behavioural studies is perceived as an element determining the strength of the process) and social system ("a set of interrelated units", (Rogers 1962, p. 23). Also Gort and Klepper (1982) define technology diffusion as the "spread in the number of producers engaged in manufacturing a new product". The definition was slightly adjusted by Adres et al. (2007), to the needs of studies on new information and communication technologies

\footnotetext{
${ }^{1}$ Concepts derived from medicine sciences.
} 
across countries. They claim that the technology diffusion can also refer to the "number of consumers of Internet" (see Andres et al. 2007).

In accordance to the diffusion of innovation theory of Rogers (Rogers 1962), concepts of theoretical diffusion patterns that countries shall follow, passing sequent steps (phases) in adoption process emerged. The adoption patterns of technology are assumed to follow S-shaped curve. The group of S-shaped curves originated from Pierre-Francois Verhulst, who in 1833 proposed the first logistic equation, explaining natural population growth. The concept of "natural growth" stands for particular ability of "species" (see Darwin 1859) for multiplying in a specified period of time. In economic sciences, "species" refer to any kind of variable which tends to grow in time. The S-shaped trajectories are mainly observed when innovation (technology) diffuses over large societies. The curve shape explains adopter population dynamics in time, assuming the heterogeneity of the whole population. Theoretical trajectory shows that technology tends to spread at high pace in early stages of diffusion process, and afterwards the diffusion rates slow as the overall saturation (share of population using given technology) of the technology in a given society is growing. It is also assumed that, after passing the "inflection point", the rate of adoption shall slow down, as higher percentage of population enjoys access to technology.

Picture 1. Theoretical S-shaped curve

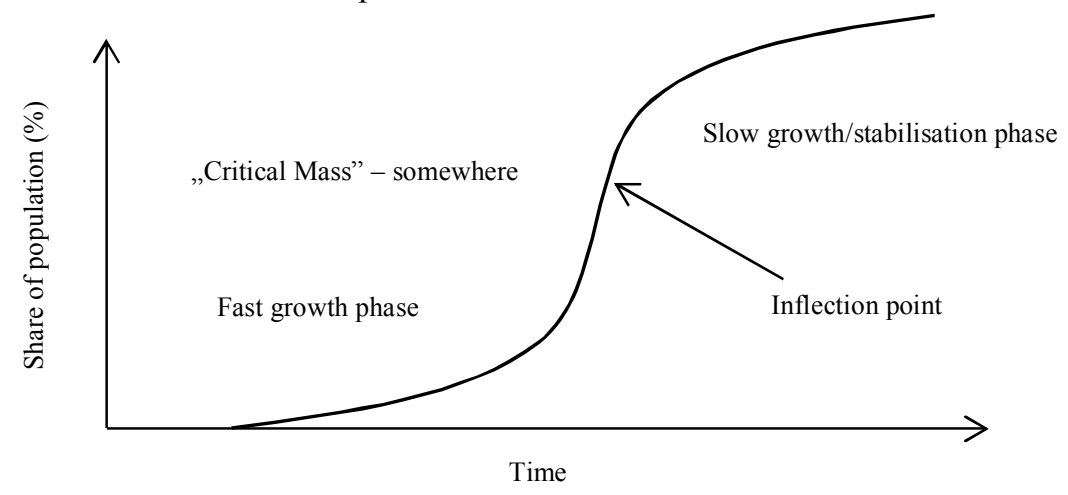

Source: own elaboration.

The general concept of the S-shaped curve explaining the stages of technology diffusion is clarified in the Picture 1. Clearly, the process of technology diffusion is fully accountable for the nature of technology itself. Certain features of technology, absorptive capacities of a society, its knowledge and skills, information asymmetries, channels of diffusion and further adoption, 
state policies - all these highly condition diffusion rates, creating friendly environment for technology diffusion or - reversely - posing barriers to the process.

\section{The Data - Preliminary Analysis}

In the following study, we concentrate exclusively on low and lower-middleincome economies, basing on broadly accepted country classification introduced by World Bank ${ }^{2}$. As a result, the country sample covers 46 economies, where 15 countries are classified as low-income and 31 - as lower-middleincome ones. The full list of countries is available in the statistical appendix (see statistical Appendix 1). The time span is set for years 2000-2011.

For the analysis purposes, we have selected 3 basic ICT indicators, treated as proxy variables of information and communication technologies. They are thought to reveal the average level of usage and application of ICT among society. Namely, we use: the share of total population using (having access to) fixed telephone lines (FTL - abbrev.); the share of population using mobile phones (we use the mobile cellular subscribers ratio; MCS - abbrev.); and the share of population (individuals) using the Internet (Internet users ratio, IU - abbrev.). All data referring were derived from World Telecommunication/ICT Indicators Database 2012 ( $16^{\text {th }}$ edition).

To get a general idea about the variables variability in low and lowermiddle-income countries, we run descriptive analysis. In Table 1 we present basic descriptive statistics of the ICT variables.

In Table 1, each variable stands for the share of total population that uses given telecommunication tool. In the analyzed period, changes in FTL adoption were slight, and did not present any crucial increases. But, turning to the following 2 variables: MCS and IU, changes in their level of basis adoption and usage were enormous. In 2000, the average share of population having adopted MCS in low and lower-middle-income countries was at 2,3\%, while - after 11 years of dynamic growth ${ }^{3}$ the level is at 76,9\%. In 2000 , the best performing country was Paraguay - with $15,3 \%$ of population using MCS, and in 2011 it was Vietnam - 144,9\% of population using mobile phones ${ }^{4}$. Similar conclusion can be drawn in the case of IU. In 2000, the average level

\footnotetext{
${ }^{2}$ World Bank classifies countries according to their per capita Gross National Income using Atlas Method as tool for international comparisons. The low-income countries are those were average annual GNI per capita does not exceed 1025 US dollars. The lower-middleincome countries are those were average annual GNI per capita varies from 1026 US dollars per capita to 4035 US dollars per capita.

${ }^{3}$ For detailed growth rates see Appendix 1.

${ }^{4}$ The number higher than $100 \%$ proves that one person subscribes more than one mobile phone.
} 
of population share defined as Internet Users was at $0,7 \%$, while in 2011 - 17,5\%. In 2000 the best performer was Belize with 5,95\% of population (individuals) using the Internet, and in 2011 - Morocco with the $51 \%$ of individuals using the Internet.

Table 1. FTL ( $\%$ of total population), MCS (\% of total population) and IU (\% of total population) - descriptive statistics. Low and lower-middle-income countries -46 economies. Years 2000 and 2011

\begin{tabular}{|c|c|c|c|c|c|c|}
\hline Variable & $\begin{array}{c}\text { Average } \\
\mathbf{( \% )}\end{array}$ & $\begin{array}{c}\text { Min.Value } \\
\mathbf{( \% )}\end{array}$ & $\begin{array}{c}\text { Max.Value } \\
\mathbf{( \% )}\end{array}$ & $\begin{array}{c}\text { Lower(first) } \\
\text { quartile (\%) }\end{array}$ & $\begin{array}{c}\text { Upper } \\
\text { (third) } \\
\text { quartile } \\
(\%)\end{array}$ & $\begin{array}{c}\text { Gini } \\
\text { coefficients }\end{array}$ \\
\hline FTL2000 & 4,4 & 0,2 & 21,2 & 0,8 & 5,3 & 0,64 \\
\hline FTL2011 & $\mathbf{7 , 3}$ & $\mathbf{0 , 3}$ & $\mathbf{3 3 , 2}$ & $\mathbf{1 , 3}$ & $\mathbf{1 0 , 5}$ & $\mathbf{0 , 6 3}$ \\
\hline MCS2000 & 2,3 & 0,0 & 15,4 & 0,2 & 2,9 & 0,73 \\
\hline MCS2011 & $\mathbf{7 6 , 9}$ & $\mathbf{2 1 , 3}$ & $\mathbf{1 4 4 , 9}$ & $\mathbf{5 5 , 8}$ & $\mathbf{9 9 , 3}$ & $\mathbf{0 , 2 5}$ \\
\hline IU2000 & 0,7 & 0,0 & 6,0 & 0,2 & 1,0 & 0,68 \\
\hline IU2011 & $\mathbf{1 7 , 5}$ & $\mathbf{1 , 3}$ & $\mathbf{5 1 , 0}$ & $\mathbf{7 , 0}$ & $\mathbf{2 8 , 0}$ & $\mathbf{0 , 4 6}$ \\
\hline
\end{tabular}

Source: own estimates based on data from World Telecommunication/ICT Indicators Database 2012 ( $16^{\text {th }}$ edition). Note: raw data applied.

The lower/upper quartile analysis also reports huge changes in the field. For MCS (in 2000) in the $25 \%$ of countries (lower quartile) the share of population using MCS was below 0,2\%, while in 2011, the analogous value reached the level of $55,8 \%$. This, again, proofs a highly dynamic diffusion and an increase in the usage of basic ICT tools in low and lower-middleincome countries.

Additionally, we report on Gini coefficients in 2000 and 2011 (again see Table 1). For FTL, changes in Gini were hardly reported, and the degree of inequality was not affected by the process of FTL diffusion. Just the opposite situation was found in case of MCS and IU. For both variables, the process of ICT diffusion affected significantly the concentration. After 11-year period of dynamic diffusion of ICT - especially for MCS - the inequality in the access to ICT diminished, and the usage of basic ICT tools became more common for all society members (for additional evidence on changes in inequalities, see Lorenz curves for FTL, MCS and IU in Appendix 3).

\section{Identifying ICT Diffusion Patterns in Low and Lower-middle Income Countries}

The main aim of the study is to identify diffusion patterns of ICT in low and lower-middle-income countries. As stated by Jovanovic and Lach (1989), 
there exists a wide empirical evidence that technology diffusion patterns follow the logistic trajectories graphically approximated by an S-shaped curve. Following the above, we expect to uncover the "classical" S-shaped diffusion curve in most of countries for ICT diffusion process. The empirical part covers 3 sections. In section 1, we aim to detect changes in the distribution of FTL, MCS and IU in all 46 economies, in 2000-2011. In the second section, we investigate if ICT diffusion patterns are distinct across income levels. Finally, in the third section, we estimate ICT diffusion patterns of FTL, MCS and IU in country sub-samples: $\mathrm{C}_{\mathrm{L}}$ (low-income countries) and $\mathrm{C}_{\mathrm{LM}}$ (lower-middle-income countries), for the analogous time span.

\section{Distribution Changes of ICT in Low and Lower-middle-income Countries}

In the first stage, we seek for changes in the distribution of ICT in the group of low and lower-middle-income countries. To capture these, we apply densities functions approach, analyzing distributions of FTL, MCS and IU adoption in terms of per 100 inhabitants $^{5}$, in 2000-2011 (see Charts 1,2 and 3).

The evidence shown in Chart 1 presents hardly no changes in the distribution and the average level of adoption on FTL, as the solid line (standing for year 2000) and dash line (standing for year 2011) overlap. Analogous conclusion could be derived from descriptive statistics in Table 1, where the only slight growth in usage of fixed phones is detected.

Chart 1. Changes in distribution of FTL (per 100 inhabit). Low and lower-middleincome countries. Years 2000 and 2011

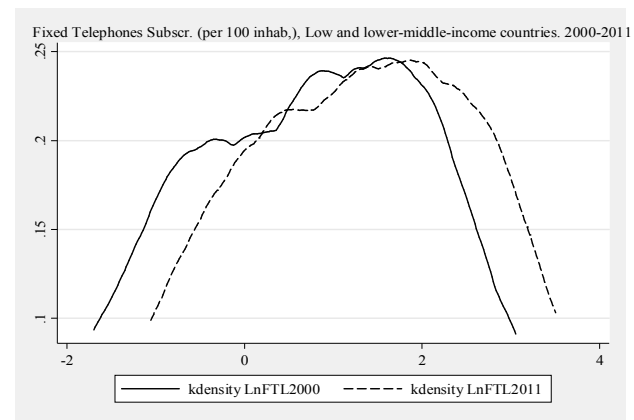

Source: own elaboration using data from World Telecommunication/ICT Indicators Database 2012.

\footnotetext{
${ }^{5}$ On the axis, the values are expressed as natural logarithms of raw data.
} 
A completely different picture is presented in Chart 2. In 2000, the average adoption/usage of mobile phones was at a relatively low level, and the level of adoption/usage in the countries in the sample was highly uneven. In 2000, high diversification is evident ${ }^{6}$.

Chart 2. Changes in distribution of MCS (per 100 inhabit). Low and lower-middleincome countries. Years 2000 and 2011

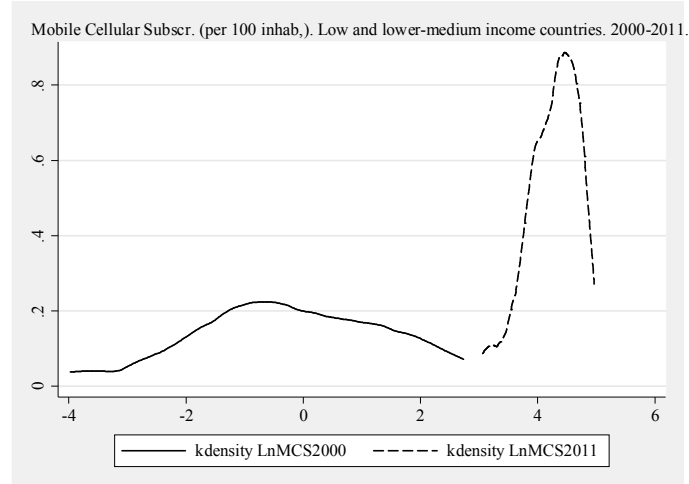

Source: own elaboration using data from World Telecommunication/ICT Indicators Database 2012.

After the 11 years (in 2011), the distribution line (dash line) has "moved" to the right and is highly peaked. It proves a much higher average level of MCS usage in the whole sample, and - on the other hand - decreases in inequalities. In terms of MCS usage, in the analyzed period, the group of low and lower-middle-income countries has become much more homogenous.

Finally, moving to the Internet Users (\% of individuals), again we identify (see Chart 3), changes of high dynamics. In 2000 (solid line), the average share of individuals using Internet was significantly lower than in 2011 (dash line), and the distributions suggest relatively high inequalities (in 2000). As in case of MCS, the distribution line for the 2011, has "moved" to the right and one high peak has emerged. It indicates diminishes in distributional disparities, and much higher average level of usage on Internet.

\footnotetext{
${ }^{6}$ Again for MCS.
} 
Chart 3. Changes in distribution of IU (\% of individuals). Low and lower-middleincome countries. Years 2000 and 2011

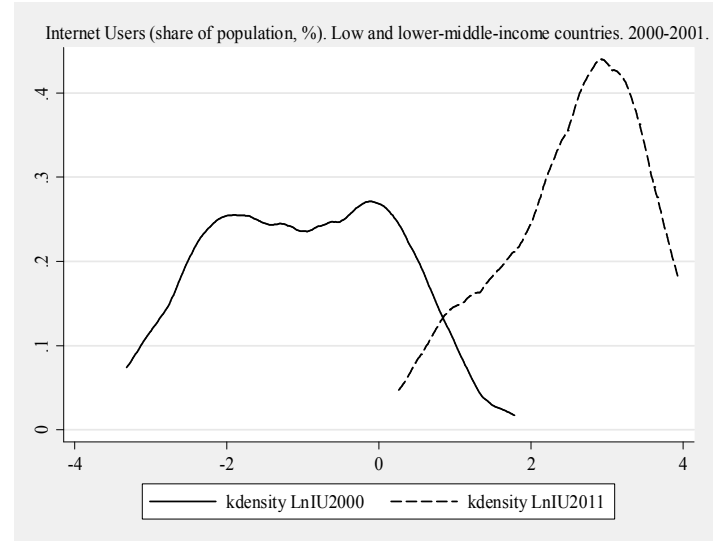

Source: own elaboration using data from World Telecommunication/ICT Indicators Database 2012.

\section{ICT Diffusion Patterns in low and Lower-middle-income Countries}

The process of technology diffusion is widely discussed on the literature. Empirical works mainly concentrate on Internet diffusion patterns, explaining rate of diffusion and the extent to which Internet is adopted by potential users. Such an analysis can be found in the works of Chong and Micco (2003), Klobas and Clyde (1998), Quibria (2002) or i.e. Estache et al. (2002). There are also several authors who intended to identify the S-shaped curve in the technology adoption process in countries. The empirical evidence on the existence of S-shaped diffusion path is reported in the works of Mansfield (1961), Jovanovic and Lach (1989), Comin et al. (2003), Andres (2008), Massenot (2008), Ania et al. (2011), or Shimogawa et al. (2012).

We assume that technology diffusion - in each country, shall follow heterogeneous path, resulting in S-shaped curved as graphical illustration of the process.

Let us assume that technology diffusion rate is a function of time, where $\phi_{j}(t)$, for $j$-country in year $t$. Following the previous, the absolute technology saturation change for $j$-country in the period ${ }^{7} t$, for given $T^{8}$-technology, can be formally expressed as:

\footnotetext{
${ }^{7}$ Assuming year-on-year estimates.

${ }^{8}$ The $T$ can stand for FTL, MCS or IU alternatively.
} 


$$
\phi_{j, t, T}=\phi_{j, t, T}-\phi_{j, t-1, T}
$$

Now, let us assume 11 periods of growth ${ }^{9}$ (years 2000-2011), so the absolute cumulative technology $(T)$ saturation change $(\Phi)$ for $n=11$ periods in $j$ country, shall be expressed as:

$$
\Phi_{j, T,(2000-2011)}=\phi_{j 1}+\phi_{j 2}+\phi_{j 3}+\ldots . . \phi_{j n}=\sum_{n=1}^{N} \phi_{n}
$$

where $\phi_{j 1}$ represents the saturation level in year $(1)$, and $\phi_{j n}$ at the end of the period - year $(n)$, in $j$ country.

If $\kappa_{j(2000)}$ stands for the initial saturation level with ICT (technology $-T$ ) in 2000 in $j$-country, then the:

$$
\vartheta_{j, T,(2011)}=\kappa_{j, T,(2000)}+\Phi_{j, T,(2000-2011)}
$$

can be identified as the final saturation level $\left(\vartheta_{j, T,(2011)}\right)$ with ICT in a $j$ country at the end of the period (in our study this shall be year 2011).

Finally, we formulate the average absolute technology saturation change $(\varphi)$ for $j$-country in $n$-year period. Again, assuming that $n=11$, this shall be formalized as:

$$
\varphi_{j, T,(2000-2011)}=\left\{\vartheta_{j, T,(2011)}-\kappa_{j, T,(2000)}\right\} / n
$$

Following the (1)-(4), we assess the cumulative absolute technology saturation change $\left(\Phi_{j, T, 2000-2011}\right)$, average absolute technology saturation change $\left(\varphi_{j, T, 2000-2011}\right)$, and the final saturation level with ICT in $2011\left(\vartheta_{j, T, 2011}\right)$ for each economy separately.

The evident inability of detailed analysis of all cases - on one hand, and - on the other hand - a danger of oversimplification if all cases (countries) were to be analyzed jointly, in the empirical part we are forced to concentrate on four representative examples of countries. These are: Fiji ${ }^{10}$, El Salvador $^{11}$, Paraguay ${ }^{12}$, and Ukraine ${ }^{13,14}$. For each country we develop 3 distinct ICT diffusion patterns (for FTL, MCS and IU separately), along with basic quantification of diffusion process. Charts 4-7, show graphical approximation of country-specific FTL, MCS and IU diffusion curves for Fiji, El Salvador, Paraguay and Ukraine.

\footnotetext{
${ }^{9}$ Diffusion.

${ }^{10} \mathrm{FJI}$ - international country code.

${ }^{11}$ SLV - international country code.

${ }^{12} \mathrm{PRY}$ - international country code.

${ }^{13}$ UKR - international country code.

${ }^{14}$ All classified as lower-medium-income countries.
} 
To clarify the picture and achieve more comparability among selected economies, in Charts 8-10 we apply mutually four diffusion curves exclusively for one ICT tool to see differences in spread and dynamic of the process in selected economies.

The most important finding is that the diffusion patterns of MCS (dashlines in Charts 4-7), form almost classical S-shaped curve. Analogous conclusion can be drawn analyzing Chart 9. The process of MCS diffusion follows similar patterns in each country. In the period 2000-2004/2005, changes in saturation with MCS level are slow, which suggest that all four countries follow the early diffusion phase. At the turn of years 2003/2004, or alternatively 2004/2005, all countries experience the "take off", passing to the next phase of diffusion, where annual changes tend to grow exponentially. Fiji experienced the fast-growth phase in years 2004-2009 (in 2010 entering the stagnation/slow growth phase), In the case of Fiji, the estimates show that $\phi_{\mathrm{Fiji}, \mathrm{MCS}(2004)}=17,36 \%{ }^{15}$, and $\phi_{\mathrm{Fiji}, \mathrm{MCS}(2007)}=63,46 \%$, which indicates that $\Phi_{\mathrm{Fiji}, \mathrm{MCS}(2003-2007)}=46,1 \%$ p. In 2008 and finally in 2011, the $\phi_{\mathrm{Fi}-}$ ${ }_{\mathrm{ji}, \mathrm{MCS}(2008)}=71,12 \%$ and $\vartheta_{\mathrm{Fiji}, \mathrm{MCS}(2011)}=83,72 \%$. For El Salvador, the fast growth phase starts in $2003-\phi_{\text {Salvador,MCS(2003) }}=19,14 \%$, ending in $2009-\phi_{\text {Salva- }}$ dor,MCS(2009) $=122,82 \%$, so $-\Phi_{\text {Salvador,MCS(2003-2009) }}=103,68 \%$. In year $2009 / 2010$ the country passes the inflection point and diffusion rates slow down. In year $2010 \phi_{\text {Salvador,MCS(2010) }}=124,34 \%$, finally in 2011 reaching $\vartheta_{\text {Salva- }}$ dor,MCS(2011) $=133,54 \%$ saturation level with MCS. In Paraguay, the fast growth phase begins in 2005 when $\phi_{\text {Paraguay,MCS(2005) }}=31,99 \%$, and end in 2008 when $\phi_{\text {Paraguay,MCS(2008) }}=92,95 \%$, which results in $\Phi_{\text {Paraguay,MCS(2005-2008) }}=60,26 \%$ p. In the final year 2011, the saturation level with ICT is reported at $\vartheta_{\text {Para- }}$ guay, $\operatorname{MCS}(2011)=99,4 \%$. For Ukraine, respective values are as follows: $\phi_{\text {Ukraine,MCS(2003) }}=13,59 \%, \quad \phi_{\text {Ukraine,MCS(2007) }}=118,77 \%, \quad \Phi_{\text {Paraguay,MCS(2003- }}$ ${ }_{2007)}=105,18 \%$ p, and finally in $2011-\vartheta_{\text {Paraguay,MCS(2011) }}=121,6 \%$.

In the fourth analyzed case, the MCS diffusion trajectory was similar and can be identified with the theoretical innovation diffusion curve explained as the S-shaped one. In each country, early MCS diffusion phases were characterized by relatively low absolute growths in the saturation level (period 2000-2003/2004). In 2003 (El Salvador), 2004 (Fiji and Ukraine), and 2005 (Paraguay), the marginal increments in absolute cumulative saturation level with MCS tend to grow. After approximately 4 years of exponential growth, each country enters the stabilization phase experiencing diminishing marginal increments in absolute cumulative saturation level.

${ }^{15}$ All the following are author's own estimates base on data from World Telecommunication/ICT Indicators Database 2012 (full version). 
Chart 4. FTL, MCS, IU diffusion patterns in El Salvador, Fiji, Paraguay and Ukraine. 2000-2011

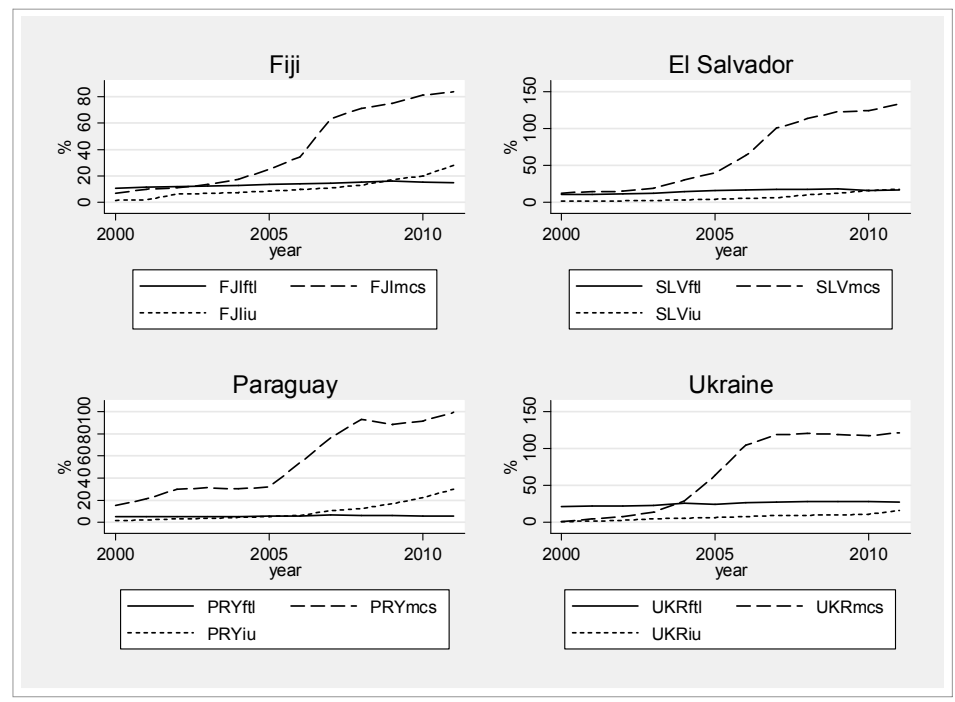

Source: own elaboration.

We also need to note, that the case of Ukraine is very particular. In the period 2000-2011, the MCS diffusion process has passed all "traditional" phases explained by S-shaped curve. In the initial period, the $\phi_{\text {Ukraine, } \operatorname{MCS}(2000)}=0,54 \%$, which proves that the adoption and usage of mobile phones was at an extremely low level - close to zero, while, after 11-year period of dynamic MCS diffusion, in 2011 the $\phi_{\text {Ukraine, } \operatorname{MCS}(2011)}=121,6 \%$, which can identified as full saturation (a whole country population has access to MCS).

For the another two ICT variables - FTL (solid-lines in Charts 4-7) and IU(dot-lines in Charts 4-7), the diffusion patterns - when compared to the diffusion pattern of MCS - are close to flat, which indicates that - in the years 2000-2011, changes in adoption of FTL and IU were relatively poor and characterized by low dynamics. 
Chart 8. FTL diffusion patterns in Fiji, El Salvador, Paraguay and Ukraine. 20002011

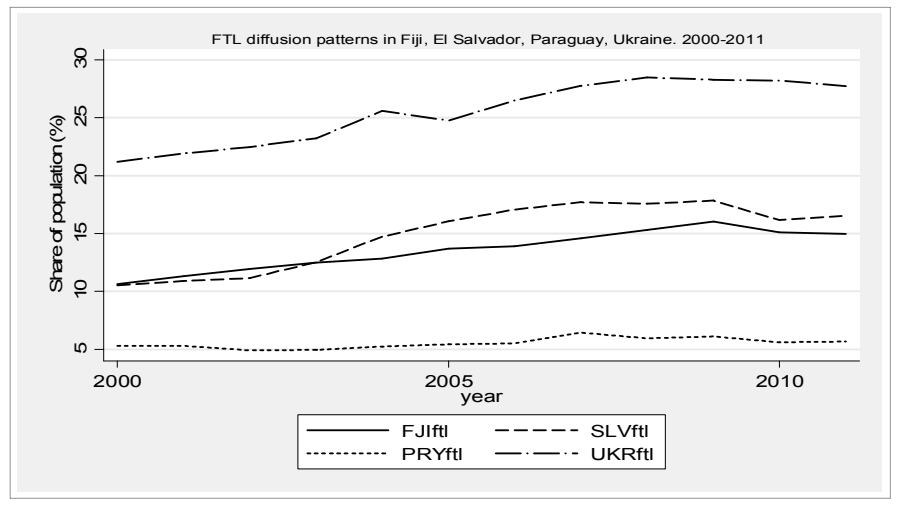

Source: own elaboration.

Chart 10. IU diffusion patterns in Fiji, El Salvador, Paraguay and Ukraine. 20002011

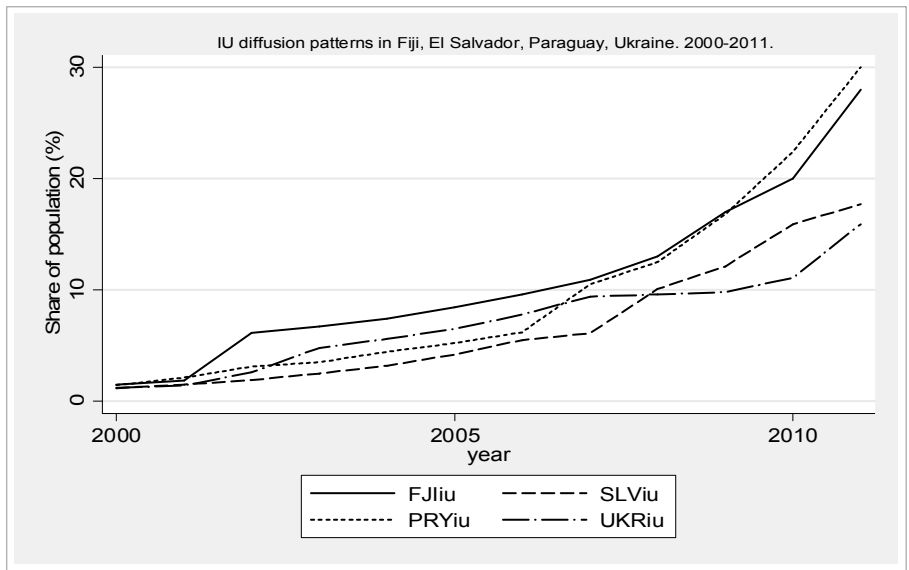

Source: own elaboration. 
Chart 9. MCS diffusion patterns in Fiji, El Salvador, Paraguay and Ukraine. 20002011

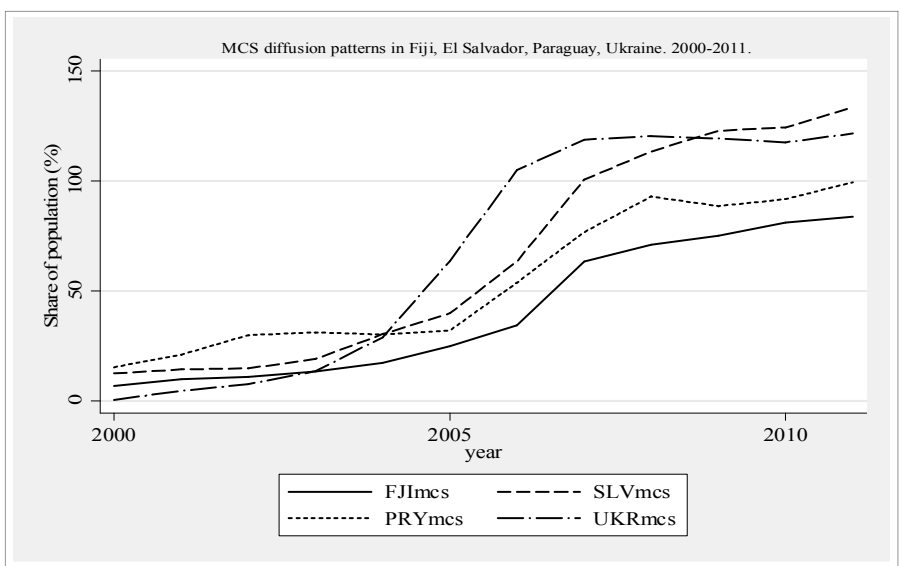

Source: own elaboration.

Giving a close look at specific diffusion trajectories of FTL and IU, we draw more detailed conclusions on the process features. Chart 10, specifies the diffusion trajectories of IU in the period 2000-2011. A graphical analysis provides the conclusion, that in 4 cases we deal with the early stages of IU diffusion process. Intuitively, we can conclude that - in year 2010 - Fiji, Paraguay and Ukraine are "taking-off" and enter path of exponential growth of IU. A common observation is that, in each country in the period 20002011 , the $\phi_{j, t, T}$ values vary significantly from year to year, resulting in no regularity.

Not surprisingly, in the case of FTL diffusion we observe only minimal changes in saturation levels. For analyzed economies, in the time span 20002011 , the diffusion characteristics are specified as: for El Salvador - $\Phi_{\text {Salva- }}$ dor,FTL(2000-2011) $=6,01 \%$ p., $\quad \vartheta_{\text {Salvador,FTL(2011) }}=16,54 \%, \quad$ and $\quad \varphi_{\text {Salvador,FTL(2000- }}$ 2011) $=0,54 \%$; for Fiji $-\Phi_{\text {Fiji,FTL(2000-2011) }}=4,31 \%$ p., $\vartheta_{\mathrm{Fiji}, \mathrm{FTL}(2011)}=14,95 \%$, and $\varphi_{\text {Fiji,FTL(2000-2011) }}=0,39 \%$; for Paraguay $-\Phi_{\text {Paraguay,FTL(2000-2011) }}=0,38 \%$ p., $\vartheta_{\text {Para- }}$ guay,FTL(2011) $=5,67 \%$, and $\varphi_{\text {Paraguay,FTL(2000-2011) }}=0,034 \%$; and for Ukraine - $\Phi_{\text {Ukraine,FTL(2000-2011) }}=6,56 \%$ p., $\vartheta_{\text {Ukraine,FTL(2011) }}=27,74 \%$, and $\varphi_{\text {Ukraine,FTL(2000- }}$ 2011) $=0,59 \%$. Although these countries enjoy different saturation levels with FTL, in the analyzed period changes on the values are visibly low. In 3 countries, approximately $6 \%$ of population gained access to fixed telephones lines ${ }^{16}$. Fixed telephony is perceived as "old ICT", and such low rates of

${ }^{16}$ In Paraguay it is only another $0,38 \%$ of population. 
growth are probably due to substitution of this of form of communication by mobile telephony. This is especially evident in low and lower-mediumincome countries with poor infrastructure. The adoption of mobile telephony does not require so high financial resources as in the case of fixed telephony, providing analogous functionalities.

In Table 2 we present summary estimates of the dynamics of ICT diffusion process in the analyzed countries. Again, we see that in 2011 the saturation levels with MCS appear to be much higher than in the case of FTL and IU. For all 4 countries, the $\vartheta_{\mathrm{j}, \mathrm{MCS}(2011)}$ reaches the level of almost $100 \%$ or even higher. This implies that almost $100 \%$ of country`s population enjoys access to a given ICT tool. Also, in the case of MCS, the developed diffusion trajectories seem to be described by an S-shaped pattern.

Table 2. Cumulative absolute technology saturation growth $\left(\Phi_{j, T, 2000-2011}\right)$, average absolute technology saturation growth $\left(\varphi_{j, T, 2000-2011}\right)$, and the final saturation level with ICT in $2011\left(\vartheta_{j, T, 2011}\right)$. Estimates for Fiji, El Salvador, Paraguay and Ukraine. Time coverage 2000-2011

\begin{tabular}{|c|c|c|c|c|c|c|c|c|c|}
\hline Country & \multicolumn{3}{|c|}{$\Phi_{j, T(2000-2011)}[\% p]$} & \multicolumn{3}{|c|}{$\begin{array}{c}\varphi_{j, T(2000-2011)} \\
\text { [annually, \%p] }\end{array}$} & \multicolumn{3}{|c|}{$\vartheta_{j, T(2011)}[\%]$} \\
\hline \multirow{2}{*}{ Fiji } & $F T L$ & $M C S$ & $I U$ & $F T L$ & $M C S$ & $I U$ & $F T L$ & $M C S$ & $I U$ \\
\hline & 4,31 & 76,9 & 26,5 & $\mathbf{0 , 3 9}$ & 6,9 & 2,4 & 14,95 & 83,7 & 28 \\
\hline \multirow{2}{*}{$\begin{array}{l}\text { El Salva- } \\
\text { dor }\end{array}$} & $F T L$ & $M C S$ & $I U$ & FTL & $M C S$ & $I U$ & $F T L$ & $M C S$ & $I U$ \\
\hline & 6,01 & 121 & 16,5 & 0,54 & 11 & 1,5 & 16,54 & 133,5 & 17,6 \\
\hline \multirow{2}{*}{ Paraguay } & $F T L$ & $M C S$ & $I U$ & $F T L$ & $M C S$ & $I U$ & $F T L$ & $M C S$ & $I U$ \\
\hline & 0,38 & 84 & 23,1 & $\mathbf{0 , 0 3}$ & 7,64 & 2,1 & 5,67 & 99,4 & 23,9 \\
\hline \multirow{2}{*}{ Ukraine } & $F T L$ & $M C S$ & $I U$ & $F T L$ & $M C S$ & $I U$ & $F T L$ & $M C S$ & $I U$ \\
\hline & 6,56 & 121 & 29,8 & 6,56 & 11 & 2,71 & 17,74 & 121 & 30,6 \\
\hline
\end{tabular}

Source: own calculations.

\section{ICT Diffusion Patterns in Country`s Sub-samples}

In the final section, we investigate the ICT diffusion curves in 2 separate country sub-samples (sub-groups) $-\mathrm{C}_{\mathrm{L}}$ (low-income) and $\mathrm{C}_{\mathrm{LM}}$ (lowermiddle-income countries). Again, we seek for S-shaped diffusion trajectories revealed in time, but applying average values for FTL, MCS and IU as variables. Chart 11 plots the evidence of the ICT diffusion paths in $\mathrm{C}_{\mathrm{L}}$ and $\mathrm{C}_{\mathrm{LM}}$ separately. Finally, we conclude on the historical evolution of the ICT diffusion in the 2 heterogeneous country groups. Despite the fact that growth rates of ICT diffusion differ significantly, regarding differences among variables and among countries, in both cases the ICT diffusion trajectories ap- 
pear to be quite similar in shape. In low-income countries (15 countries in the group), the highest saturation level is reported for MCS (for variablespecific diffusion patterns see Chart 12(b)) - in 2011, the average level of $\bar{\vartheta}_{M C S(2011), \text { Low }}=58,62 \%$ (average share of population using MCS), with the average annual diffusion growth rate $43 \%$. The 2 best performing economies were Kyrgyzstan and Cambodia, with the share of population using MCS equivalent to $\vartheta_{\mathrm{MCS}(2011)}=113 \%$ and $\vartheta_{\mathrm{MCS}(2011)}=96 \%$ respectively.

Charts 11(a),11(b). ICT diffusion curves (FTL, MCS and IU) in low-income and lower-middle-income countries. 2000-2011

Chart 11(a)

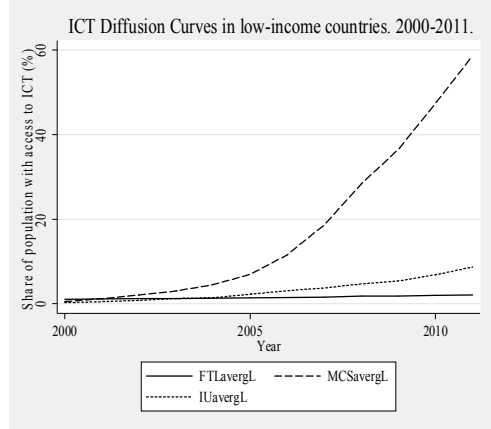

Chart 11(b)

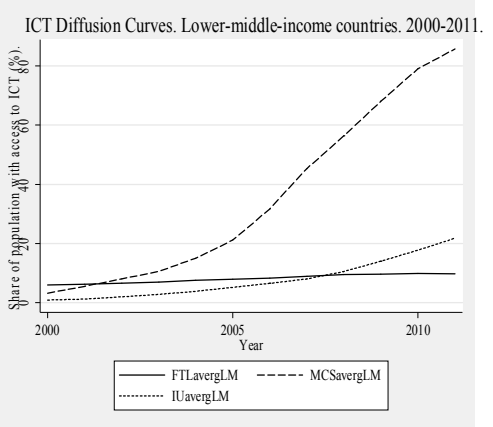

Source: own elaboration.

For the analogous variable, in lower-middle-income countries, the average saturation level equals for $\bar{\vartheta}_{M C S(2011) \text {,Lower-middle }}=85,69 \%$, with the average annual diffusion growth rate at $30 \%$ (the 2 best performers are El Salvador and Ukraine, with $\vartheta_{\mathrm{MCS}(2011)}=133 \%$ and $\vartheta_{\mathrm{MCS}(2011)}=121 \%$ respectively).

In case of IU, the diffusion trajectories stand for the initial "parts" of the theoretical S-shaped curve, indicating that the IU diffusion, both on $\mathrm{C}_{\mathrm{L}}$ and $\mathrm{C}_{\mathrm{LM}}$, refer to the early stages of diffusion process. For the given variable, in low-income countries the $\bar{\vartheta}_{I U(2011), \text { Low }}=8,69 \%$, and in lower-middleincome ones $-\bar{\vartheta}_{I U(2011), \text { Lower-middle }}=21,78 \%$. In low-income economies, the Internet usage is still at relatively low level, however in 2010 and 2011 the average absolute change in saturation level are: $\bar{\phi}_{I U(2010), \text { Low }}=$ $1,44 \% p$, and $\bar{\phi}_{I U(2011), \text { Low }}=1,86 \% p$ respectively, which predicts entering exponential growth phase. In lower-middle-income countries, marginal increments in total saturation level begin to grow slowly right in 2000, in 2008 
and 2009 achieving the average level of $\bar{\phi}_{I U(2007 / 2008), \text { Lower-middle }}=$ $1,05 \% p$ and $\bar{\phi}_{I U(2008 / 2009), \text { Lower-middle }}=0,93 \% p$ respectively.

Charts 12(a), 12(b), 12(c). FTL, MCS and IU diffusion patterns low and lowermiddle-income countries. 2000-2011.

Chart (12(s)

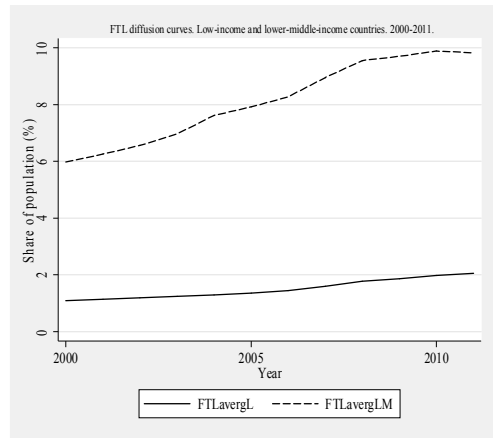

Chart 12(b)

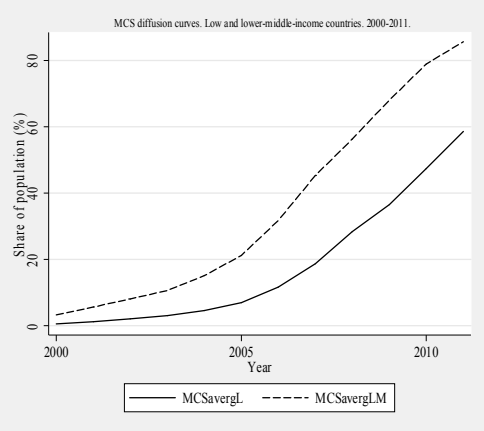

Chart $12(\mathrm{c})$

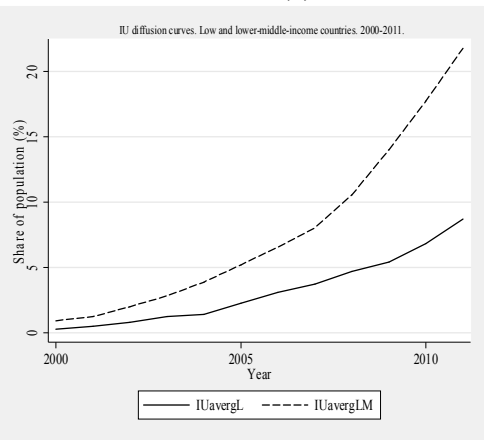

Source: own elaboration.

The FTL diffusion process is hardly visible in both country groups, revealing little higher dynamic in lower-middle-income countries than in lowincome ones. The average saturation in 2011 , for $\mathrm{C}_{\mathrm{L}}$ and $\mathrm{C}_{\mathrm{LM}}$, results as $\bar{\vartheta}_{F T L(2011), L o w}=2,06 \%$ and $\bar{\vartheta}_{F T L(2011), \text { Lower-middle }}=9,82 \%$. At a time, no logistic curve is displayed. This again confirms the hypothesis on the growing substitution of "old" ICT by "new" ones. In low-income and lowermiddle-income economies, the process of substitution can be noticed by no difficulties. This is mainly due to special features of ICT. The easiness of adoption and usage, minimum financial and infrastructural requirements 
make them an attractive development tool, especially in low and lowermiddle-income countries.

\section{Conclusions}

Diffusion is the process of spread of innovation over social system over time. Our empirical investigation encompasses ICT diffusion (Fixed Telephones Lines subscribers, Mobile Cellular Subscribers and Internet Users) in the sample of low and lower-middle-income countries (46), over the period 2000-2011. Most of countries applied for the study, have undergone massive digital revolution, where ICT have diffused at high pace. Concluding again from preliminary descriptive statistics, the average adoption has increased significantly in case of MCS and IU, being rather stable for FTL. Graphical analysis shows that the process of ICT diffusion is relatively wellcharacterized by an S-shaped trajectory. The S-shape-like diffusion curve is particularly clearly identified in the case of MCS diffusion in both country groups. Most of countries in lower-middle-income group have already passed the "classical" diffusion path stages, achieving close to maximum $(100 \%)$ saturation level. These finding suggests that in these countries almost $100 \%$ of country`s population enjoys access to mobile telephony. Such extraordinary results in MCS implementation, explain why the fixed telephony network has hardly diffused in the analogous period. The process of the Internet spread, in most countries, still remains at the early stages of diffusion. The existence of the S-shape trajectory is not evident. In 2011, the share of population identified as Internet users, was still at a relatively low level. At that time, the process of IU diffusion was not characterized by such high dynamics as in case of MCS.

Our analysis was not a long-term one (2000-2011), and was limited strictly to the analysis of low and lower-middle-income countries. In general, it can be concluded that despite diversity in ICT diffusion paths in countries, the process is characterized by high dynamics and wide spread of new technologies is observed. The finding is seminal, for further economic growth and development perspectives in backward economies.

\section{References}

Andrés L., Cuberes D., Diouf M.A., Serebrisky T. (2007), Diffusion of the Internet: a cross-country analysis, Policy Research Working Paper 4420, World Bank.

Baliamoune-Lutz M. (2003), An analysis of the determinants and effects of ICT diffusion in developing countries, "Information Technology for Development", Vol. 10, http://dx.doi.org/10.1002/itdj.1590100303. 
Billon M., Lera-Lopez F., Marco R. (2010), Differences in digitalization levels: a multivariate analysis studying the global digital divide, "Review of World Economy”, Vol. 146, http://dx.doi.org/10.1007/s10290-009-0045-y.

Chong A., Micco A. (2003), The Internet and the ability to innovate in Latin America, "Emerging Markets Review", Vol. 4, http://dx.doi.org/10.1016/S15660141(02)00063-8.

Comín D., Hobijn B. (2003), Cross-Country Technology Adoption: Making the Theories Face the Facts, Paper prepared for the Carnegie Rochester Conference on Public Policy.

Darwin C. (1859), The origin of species, John Murray, London.

Dasgupta P., Stoneman P. (2005), Economic Policy and Technological Performance, Cambridge University Press.

De Guio R., Kucharavy D. (2007), Application of S-shaped curves, TRIZ-Future Conference 2007: Current Scientific and Industrial Reality, Frankfurt.

Estache A., Manacorda M., Valletti T.M. (2002), Telecommunications, Reform, Access Regulation, and Internet Adoption in Latin America, "Economía", Vol. 2, http://dx.doi.org/10.1353/eco.2002.0003.

Geroski P.A. (2000), Models of technology diffusion, "Research Policy", Vol. 29.

Goldfarb A., Prince J. (2008), Internet adoption and usage patterns are different: implications for the digital divide, "Information Economics and Policy", Vol. 20, http://dx.doi.org/10.1016/j.infoecopol.2007.05.001.

Gort M., Klepper S. (1982), Time paths in the diffusion of product innovation, "The Economic Journal", Vol. 92, http://dx.doi.org/10.2307/2232554.

Gray V. (1973), Innovation in the States. A Diffusion Study, "The American Political Science Review", Vol. 67, No. 4, http://dx.doi.org/10.2307/1956539.

Grazzi M., Vergara S. (2008), What drives ICT diffusion in developing countries? Evidence from Paraguay, Division of Production, Productivity and Management, CEPAL, United Nations.

Hobijn B., Comin D. (2003), Cross-country technology adoption: making the theories face the facts, "Journal of Monetary Economics", Vol. 51.

Jovanovic B., Lach S. (1989), Entry, Exit, and Diffusion with Learning by Doing, “American Economic Review", Vol. 79, No. 4.

Karshenas M., Stoneman P. (1995), Technological diffusion [in:] Stoneman I. (ed.) Handbook of Economic of Innovation and Technological Change, Blackwell. Cambridge.

Keller W. (2001), International technology diffusion, NBER Working Paper 8573.

Klobas J.E., Clyde L.A. (1998), Learning to use the internet in a developing country: validation of a user model, "Libri", Vol. 48.

Mansfield E. (1961), Technical Change and the Rate of Imitation, "Econometrica", Vol. 29, No. 4, http://dx.doi.org/10.2307/1911817.

Lechman E. (2012), Catching-up and club convergence from cross-national perspective. A statistical study for the period 1980-2010, "Equilibrium. Quarterly Journal of Economics and Economic Policy", Vol.7, No. 3.

Lechman E. (2012), Technology convergence and digital divides. A country-level evidence for the period 2000-2010, "Ekonomia. Rynek, gospodarka, społeczeństwo", No. 12. 
Mansfield E. (1968), The economics of technological change, W.W Norton\&Company Inc., New York.

Metcalfe J.S. (1988), The diffusion of innovation: an interpretive survey [in:] G. Dosi et al.(ed.), Technological Change and Economic Theory, Pinter, London.

Modis T. (2007), From my perspective. Strengths and weaknesses of S-curves, "Technology Forecasting \& Social Change", Vol. 74.

Rogers M.E. (1962), Diffusion of innovation, The Free Press, London.

Romero Ania A., Alonso Neira M.A., Blanco Jimenez F.J., Fernandez-Cano E. del A. (2012), Modelling and prediction of Internet diffusion in the African continent: the s-shaped Internet diffusion curve, Proceedings $25^{\text {th }}$ European Conference on Modelling and Simulation ECMS, Burczyński T., Kołodziej J., Byrski A., Carvalho M. (ed.).

Quibria M.G., Ahmed S.N., Tschang T., Reyes-Macasaquit M.L. (2002), Digital Divide: Determinants and Policies with Special Reference to Asia, "Economics and Research Department Working Paper", No. 27, Asia Development Bank, Manila, http://dx.doi.org/10.1016/S1049-0078(02)00186-0.

Sahin I. (2006), Detailed review of Roger's diffusion of innovation theory and educational technology-related studies based on Roger's theory, "The Turkish Online Journal of Educational Technology", Vol. 5, No. 2.

Sarkar J. (1998), Technological diffusion: alternative theories and historical evidence, "Journal of Economic Surveys", Vol. 12, No.2, http://dx.doi. org/10.1111/1467-6419.00051.

Schumpeter J.A. (1934), Theory of economic development, Transaction Publishers.

Schumpeter J.A. (1947), The creative responses in economic history, "Journal of Economic History", Vol. 7.

Shimogawa S., Shinno M., Saito H. (2012), Structure of S-shaped growth in innovation diffusion, "Physical Review", Vol. 85, http://dx.doi.org/ 10.1103/PhysRevE.85.056121.

Soete L., Verspagen B. (1993), Technology and growth: the complex dynamics of catching-up, falling behind and taking over, "Explaining Economic Growth", (http://ideas.repec.org/p/ner/maastr/urnnbnnlui27-6312.html).

Stoneman P. (2001), The economics of technological diffusion, Blackwell, Oxford.

Udo G., Bagchi K.K., Kirs P.J. (2008), Diffusion of ICT in developing countries: a qualitative differential analysis of four nations, "Journal of Global Information Technology Management", Vol. 11, No. 1. 


\section{Statistical Appendix 1.}

Table 1. Basic ICT statistics for low-income and lower-middle-income countries (47 countries. Low-income countries are put in bolds). Years 2000 and 2011

\begin{tabular}{|c|c|c|c|c|c|c|c|c|c|c|}
\hline & & \multicolumn{3}{|c|}{$\begin{array}{c}\text { Fixed-telephone subscriptions. } \\
\text { Share of total population having } \\
\text { access to fixed-telephone lines } \\
(\%) \text {. }\end{array}$} & \multicolumn{3}{|c|}{$\begin{array}{l}\text { Mobile-cellular telephone subscrip- } \\
\text { tions. Share of population with active } \\
\text { mobile-cellular telephones }(\%) \text {. }\end{array}$} & \multicolumn{3}{|c|}{$\begin{array}{c}\text { Percentage of individuals using } \\
\text { the Internet }(\%)\end{array}$} \\
\hline & & $\begin{array}{l}\text { FTL } \\
\text { in } \\
2000\end{array}$ & $\begin{array}{l}\text { FTL } \\
\text { in } \\
2011\end{array}$ & $\begin{array}{l}\text { FTL average } \\
\text { annual } \\
\text { exponential } \\
\text { growth rate } \\
\text { in 2000-2011 } \\
\text { (approxima- } \\
\text { tions) }\end{array}$ & $\begin{array}{l}\text { MCS } \\
\text { in } \\
2000\end{array}$ & $\begin{array}{l}\text { MCS } \\
\text { in } \\
2011\end{array}$ & $\begin{array}{l}\text { MCS average } \\
\text { annual exponen- } \\
\text { tial growth rate } \\
\text { in 2000-2011 } \\
\text { (approximations) }\end{array}$ & $\begin{array}{l}\text { IU in } \\
2000\end{array}$ & $\begin{array}{l}\text { IU in } \\
2011\end{array}$ & $\begin{array}{c}\text { IU } \\
\text { average } \\
\text { annual } \\
\text { exponen- } \\
\text { tial } \\
\text { growth } \\
\text { rate in } \\
2000- \\
2011 \\
\text { (approx- } \\
\text { imations) }\end{array}$ \\
\hline Albania & ALB & 4,97 & 10,54 & $7 \%$ & 0,97 & 96,39 & $42 \%$ & 0,11 & 49,00 & $55 \%$ \\
\hline Armenia & ARM & 17,34 & 18,63 & $1 \%$ & 0,57 & 103,57 & $47 \%$ & 1,30 & 32,00 & $29 \%$ \\
\hline Bangladesh & BGD & 0,38 & 0,65 & $5 \%$ & 0,22 & 56,06 & $51 \%$ & 0,07 & 5,00 & $39 \%$ \\
\hline Belize & BLZ & 14,31 & 8,09 & $-4 \%$ & 6,73 & 62,37 & $21 \%$ & 5,96 & 15,19 (a) & $8 \%$ \\
\hline Bolivia & BOL & 6,15 & 8,71 & $3 \%$ & 7,01 & 82,82 & $22 \%$ & 1,44 & 30,00 & $28 \%$ \\
\hline $\begin{array}{l}\text { Burkina } \\
\text { Faso }\end{array}$ & BFA & 0,43 & $\mathbf{0 , 8 3}$ & $6 \%$ & 0,21 & 45,27 & $49 \%$ & 0,08 & 3,00 & $33 \%$ \\
\hline Cambodia & KHM & 0,25 & 3,70 & $25 \%$ & 1,05 & 96,17 & $41 \%$ & 0,05 & 3,10 & $38 \%$ \\
\hline Cote d'Ivoire & CIV & 1,59 & 1,33 & $-2 \%$ & 2,85 & 86,06 & $31 \%$ & 0,23 & 2,20 & $20 \%$ \\
\hline Djibouti & DJI & 1,33 & 2,04 & $4 \%$ & 0,03 & 21,32 & $59 \%$ & 0,19 & 7,00 & $33 \%$ \\
\hline El Salvador & SLV & 10,53 & 16,54 & $4 \%$ & 12,52 & 133,54 & $22 \%$ & 1,18 & 17,69 & $25 \%$ \\
\hline Fiji & FJI & 10,64 & 14,95 & $3 \%$ & 6,78 & 83,72 & $23 \%$ & 1,50 & 28,00 & $27 \%$ \\
\hline Georgia & GEO & 11,51 & 29,98 & $10 \%$ & 4,41 & 98,73 & $29 \%$ & 0,48 & 36,56 & $39 \%$ \\
\hline Ghana & GHA & 1,11 & 1,14 & $0 \%$ & 0,68 & 84,78 & $44 \%$ & 0,15 & 14,11 & $41 \%$ \\
\hline Honduras & HND & 4,80 & 7,86 & $4 \%$ & 2,50 & 103,97 & $34 \%$ & 1,20 & 15,90 & $23 \%$ \\
\hline India & IND & 3,08 & 2,63 & $-1 \%$ & 0,34 & 72,00 & $49 \%$ & 0,53 & 10,07 & $27 \%$ \\
\hline Indonesia & IDN & 3,12 & 15,94 & $15 \%$ & 1,72 & 103,09 & $37 \%$ & 0,93 & 18,00 & $27 \%$ \\
\hline Kenya & KEN & 0,93 & 0,68 & $-3 \%$ & 0,41 & 67,49 & $46 \%$ & 0,32 & 28,00 & $41 \%$ \\
\hline Kyrgyzstan & KGZ & 7,68 & 9,12 & $2 \%$ & 0,18 & 113,98 & $59 \%$ & 1,04 & 20,00 & $27 \%$ \\
\hline Lao PDR & LAO & 0,77 & 1,71 & $7 \%$ & 0,24 & 87,16 & $54 \%$ & 0,11 & 9,00 & $40 \%$ \\
\hline Lesotho & LSO & 1,13 & 1,76 & $4 \%$ & 1,10 & 56,17 & $36 \%$ & 0,21 & 4,22 & $27 \%$ \\
\hline Madagascar & MDG & 0,36 & 0,65 & $5 \%$ & 0,41 & 40,65 & $42 \%$ & 0,20 & 1,90 & $21 \%$ \\
\hline Malawi & MWI & 0,41 & 1,13 & $9 \%$ & 0,44 & 25,69 & $37 \%$ & 0,13 & 3,33 & $30 \%$ \\
\hline Mauritania & MRT & 0,72 & 2,04 & $10 \%$ & 0,58 & 93,60 & $46 \%$ & 0,19 & 4,50 & $29 \%$ \\
\hline Moldova & MDA & 16,04 & 33,15 & $8 \%$ & 3,82 & 104,38 & $31 \%$ & 1,28 & 38,00 & $31 \%$ \\
\hline Mongolia & MNG & 4,87 & 6,70 & $3 \%$ & 6,41 & 105,08 & $25 \%$ & 1,26 & 20,00 & $25 \%$ \\
\hline Morocco & MAR & 4,95 & 11,05 & $7 \%$ & 8,13 & 113,26 & $24 \%$ & 0,69 & 51,00 & $39 \%$ \\
\hline Nepal & NPL & 1,09 & 2,77 & $8 \%$ & 0,04 & 43,81 & $63 \%$ & 0,20 & 9,00 & $34 \%$ \\
\hline Niger & NER & 0,18 & $\mathbf{0 , 5 3}$ & $10 \%$ & 0,02 & 29,52 & $67 \%$ & 0,04 & 1,30 & $33 \%$ \\
\hline Nigeria & NGA & 0,45 & 0,44 & $0 \%$ & 0,02 & 58,58 & $71 \%$ & 0,06 & 28,43 & $55 \%$ \\
\hline Pakistan & PAK & 2,11 & 3,24 & $4 \%$ & 0,21 & 61,61 & $52 \%$ & 1,11 (a) & 9,00 & $19 \%$ \\
\hline Paraguay & PRY & 5,29 & 5,67 & $1 \%$ & 15,36 & 99,40 & $17 \%$ & 0,75 & 23,90 & $31 \%$ \\
\hline Philippines & PHL & 3,96 & 3,75 & $0 \%$ & 8,35 & 99,30 & $23 \%$ & 1,98 & 29,00 & $24 \%$ \\
\hline Rwanda & RWA & 0,22 & 0,36 & $4 \%$ & 0,48 & 40,63 & $40 \%$ & 0,06 & 7,00 & $43 \%$ \\
\hline Sri Lanka & LKA & 4,02 & 17,29 & $13 \%$ & 2,25 & 87,78 & $33 \%$ & 0,65 & 15,00 & $29 \%$ \\
\hline Swaziland & SWZ & 3,15 & 7,10 & $7 \%$ & 3,26 & 71,79 & $27 \%$ & 0,93 & 18,13 & $27 \%$ \\
\hline Syria & SYR & 10,48 & 20,87 & $6 \%$ & 0,19 & 63,00 & $53 \%$ & 0,18 & 22,50 & $44 \%$ \\
\hline Tanzania & TZA & 0,51 & 0,35 & $-3 \%$ & 0,32 & 55,53 & $47 \%$ & 0,12 & 12,00 & $42 \%$ \\
\hline Togo & TGO & 0,89 & 3,90 & $13 \%$ & 1,04 & 50,45 & $35 \%$ & $\mathbf{0 , 8 0}$ & 3,50 & $13 \%$ \\
\hline Uganda & UGA & 0,25 & 1,35 & $15 \%$ & 0,52 & 48,38 & $41 \%$ & 0,16 & 13,01 & $40 \%$ \\
\hline Ukraine & UKR & 21,18 & 27,74 & $3 \%$ & 0,52 & 121,60 & $39 \%$ & 0,72 & 30,60 & $34 \%$ \\
\hline Uzbekistan & UZB & 6,71 & 6,57 & $0 \%$ & 0,22 & 86,71 & $55 \%$ & 0,48 & 30,20 & $38 \%$ \\
\hline Vanuatu & VUT & 3,59 & 2,54 & $-3 \%$ & 0,20 & 55,76 & $51 \%$ & 2,11 & $9,06(\mathrm{a})$ & $13 \%$ \\
\hline Vietnam & VNM & 3,28 & 11,58 & $12 \%$ & 1,02 & 144,94 & $45 \%$ & 0,25 & 35,07 & $45 \%$ \\
\hline Yemen & YEM & 1,96 & 4,33 & $7 \%$ & 0,18 & 47,05 & $51 \%$ & 0,08 & 14,91 & $47 \%$ \\
\hline Zambia & ZMB & 0,82 & 0,64 & $-2 \%$ & 0,97 & 60,59 & $38 \%$ & 0,19 & 11,50 & $37 \%$ \\
\hline Zimbabwe & ZWE & 1,99 & 2,79 & $3 \%$ & 2,13 & 72,13 & $32 \%$ & 0,40 & 15,70 & $33 \%$ \\
\hline
\end{tabular}

Source: Own estimates based on data derived from World Telecommunication/ICT Indicators

Database 2012 (16 ${ }^{\text {th }}$ edition) and World Development Indicators 2012. (a) - estimates based on time-trend exponential growth rates (author`s own calculations). 
Appendix 2. Country-specific diffusion curves for FTL, MCS, IU. Low and lower-middle-income countries. 2000-2011
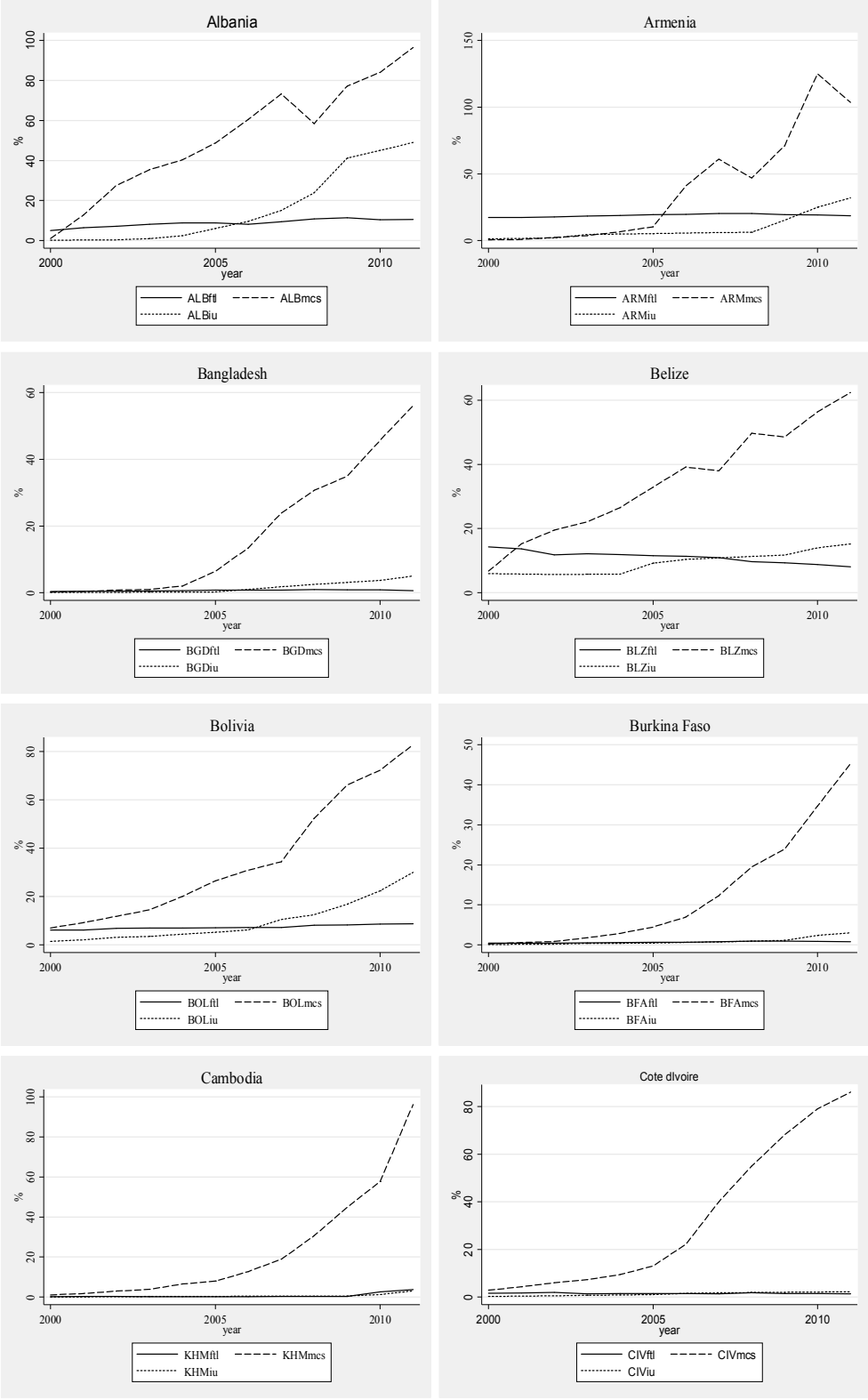

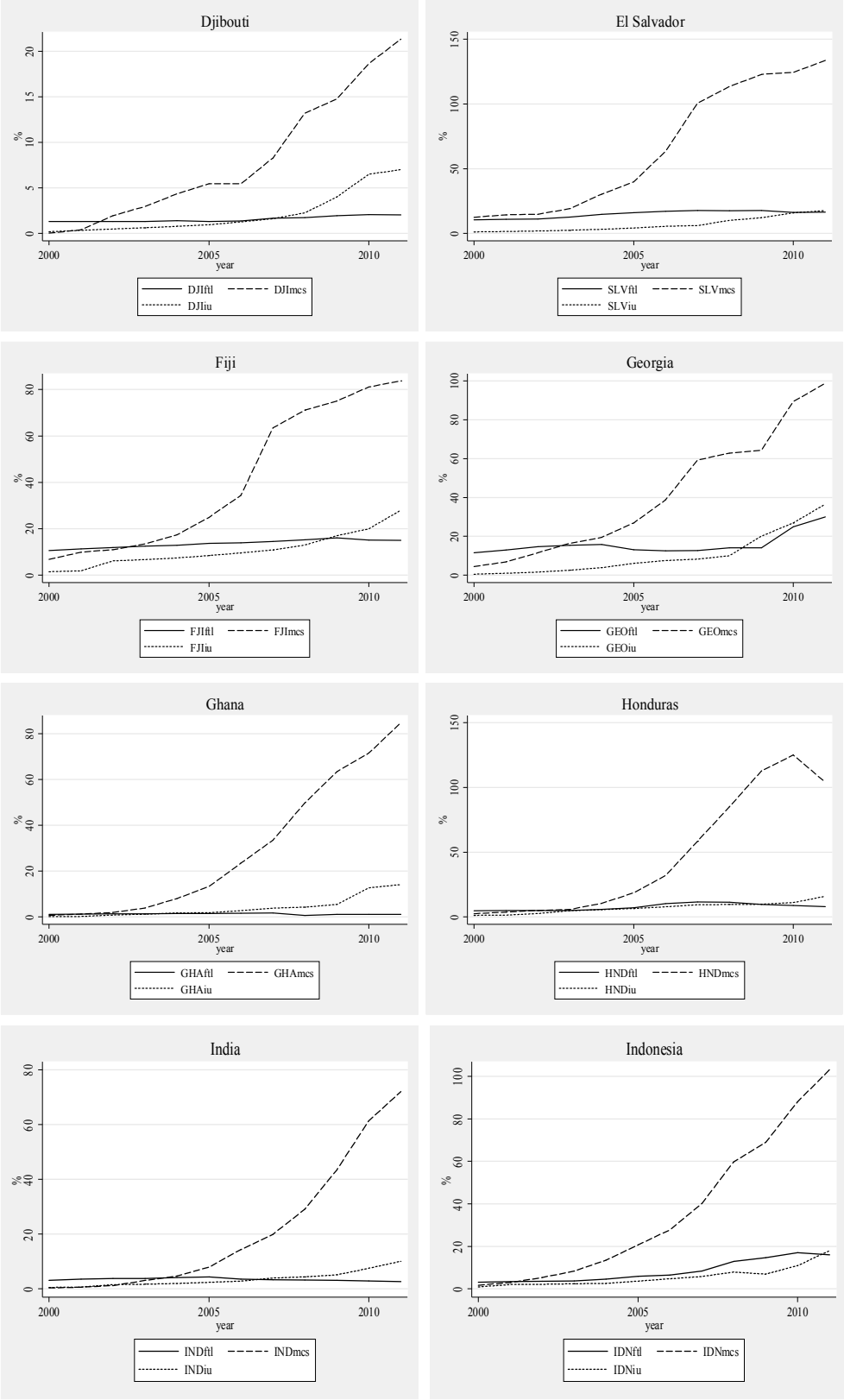

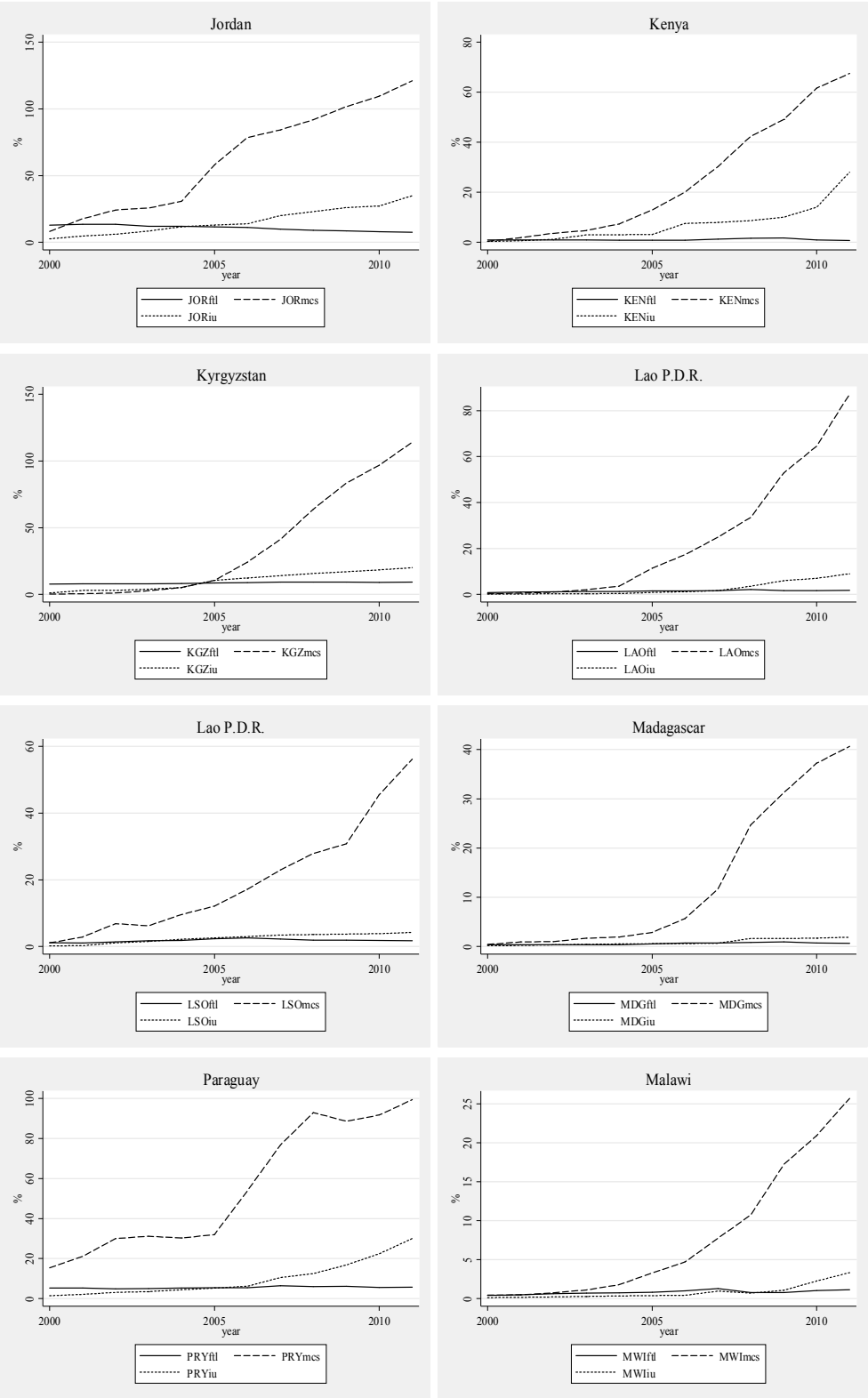

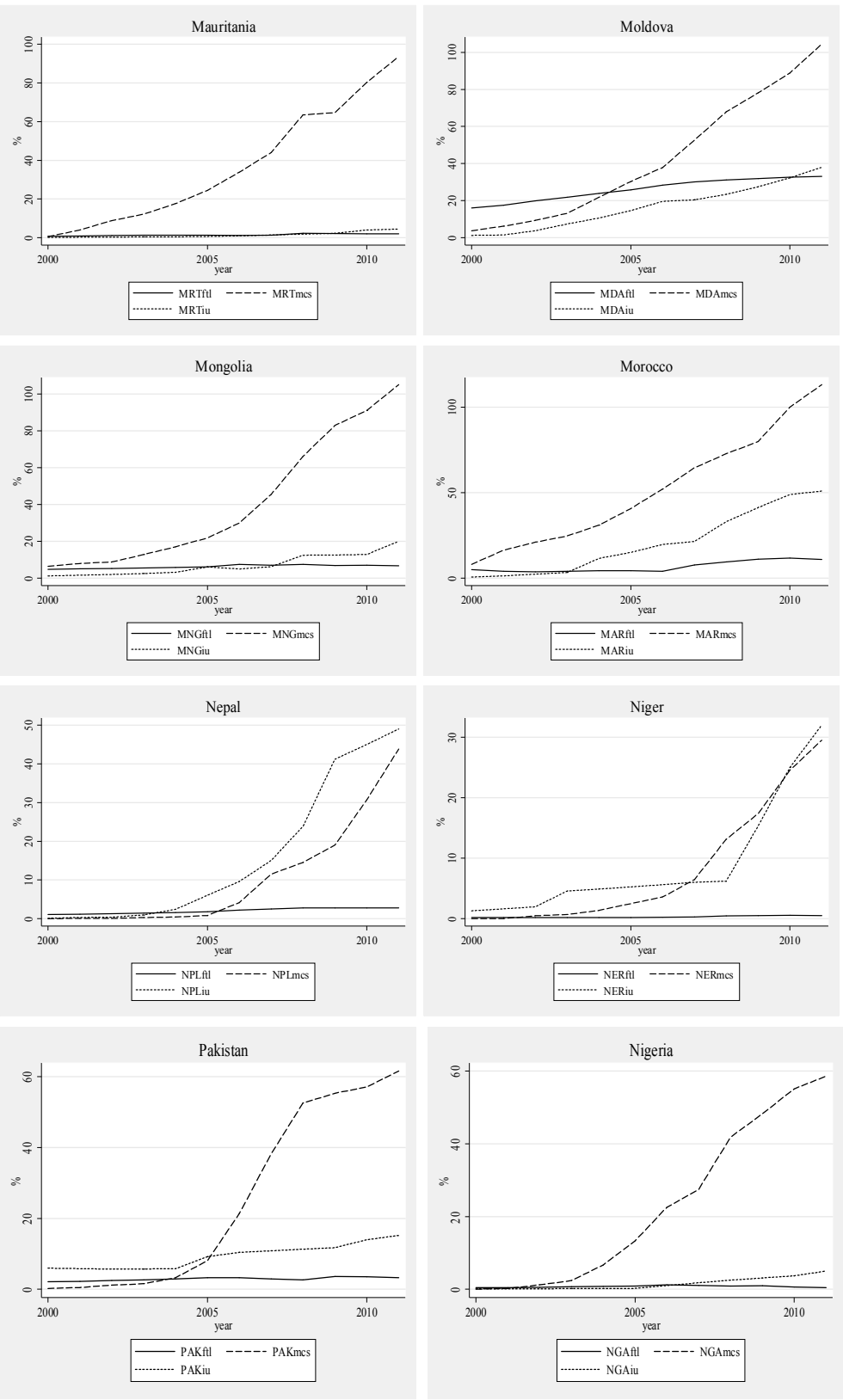

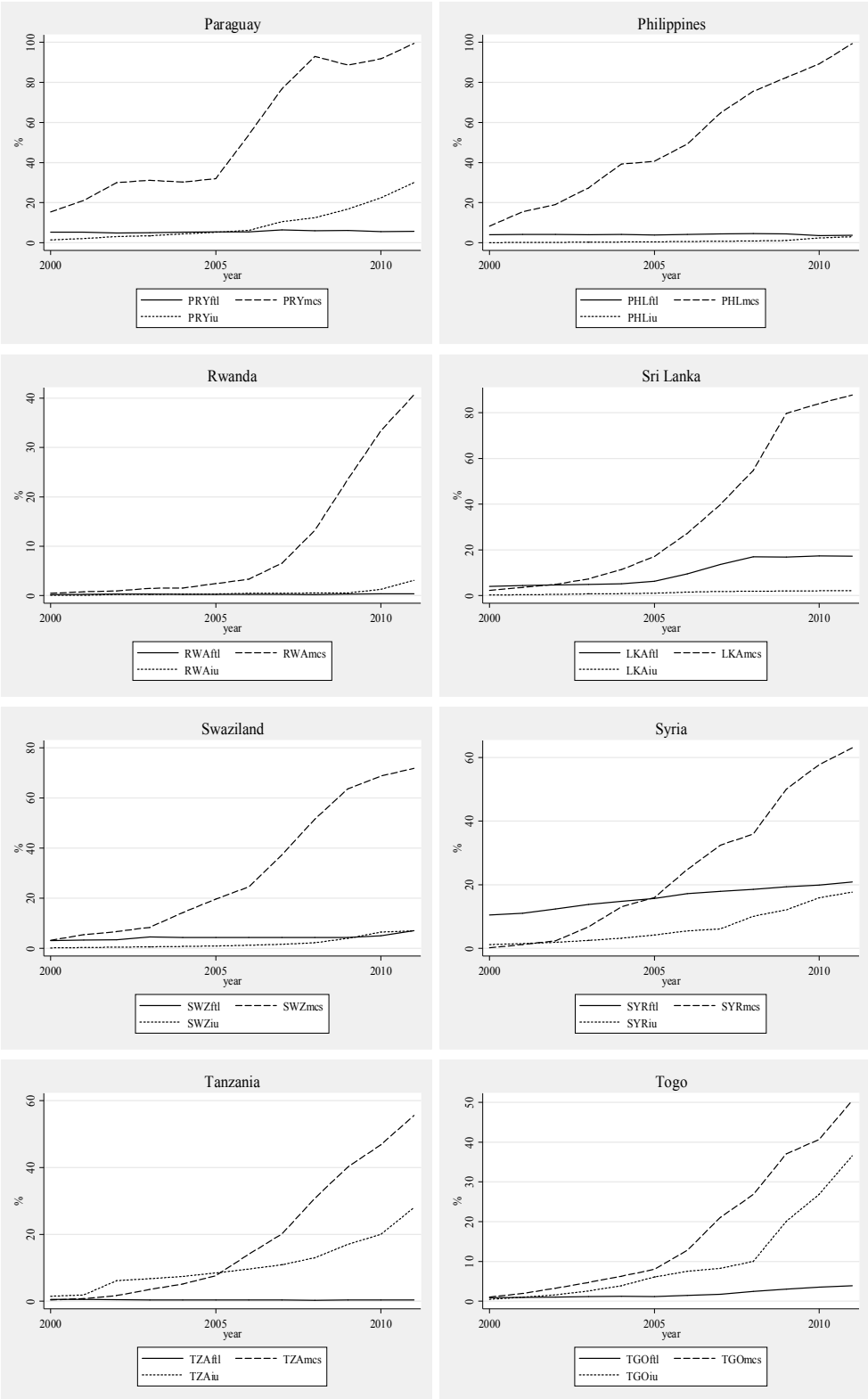

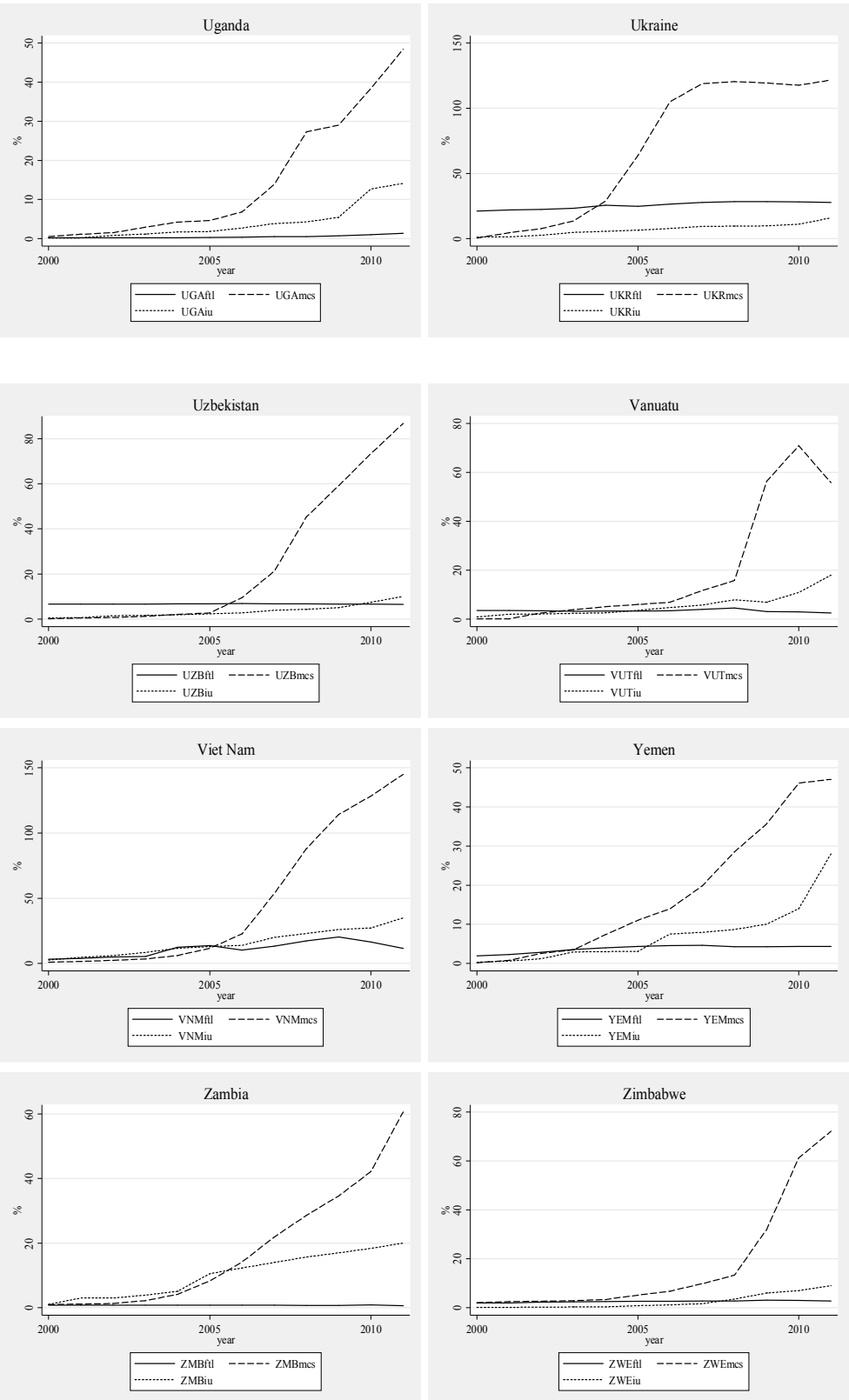
Appendix 3. Lorenz curves for FTL, MCS, IU. Years 2000 and 2011. Low and lower-middle-income countries
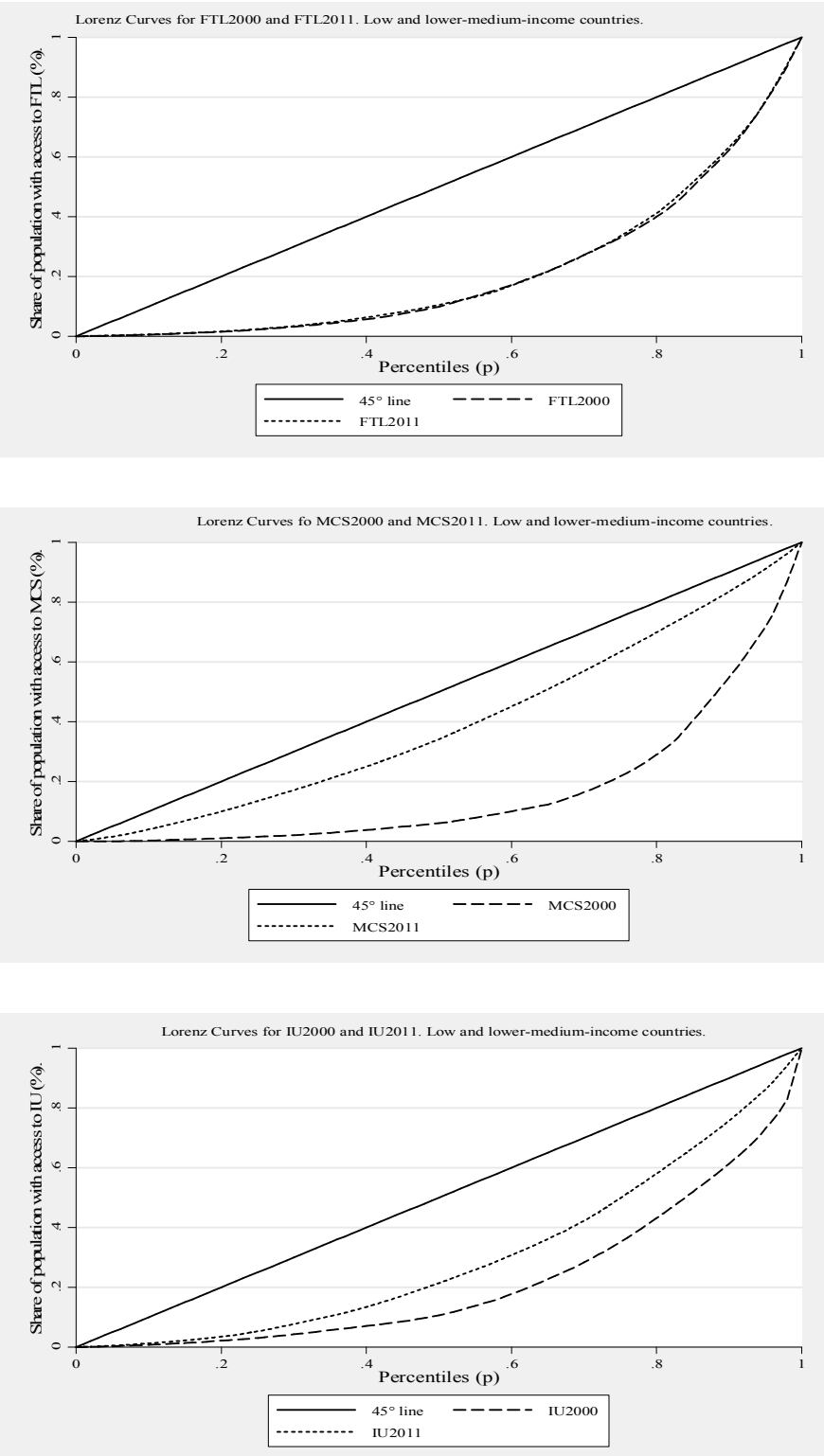

Source: own elaboration. 